\title{
10 Threats, risks, and the (re)turn to territorial security policies in Sweden
}

\author{
Jonatan Stiglund
}

\section{Introduction}

Nordic, and particularly Swedish, security policies have undergone a significant discursive shift in focus during the 2010s, with 2014 representing a decisive year for a change of direction. The Russian annexation of Crimea and instigating of war in eastern Ukraine that year came to be understood as meaning new geopolitical realities for European security, which Swedish security elites had to consider and take into account in their assessments and policies (Agrell, 2016; Ds 2017:66, ${ }^{1}$ p. 17). The proponents of the shift towards increased long-term defence spending, territorial defence, hostile intentions, and hybrid warfare as core parameters of security argued that this change was long overdue and one that Sweden was particularly illpositioned to make at this point in time (Sveriges Television, 2015). The background is the, until that point, long-established understanding dominating official Swedish security policy about an increasingly peaceful Europe, and that security had come to concern not existential threats to the state and its citizens, but domestic problems related to non-military matters and international security abroad (Agrell, 2016). Swedish governments had since the early 1990s successively dismantled the capabilities and resources designed to confront military assets of hostile actors that might pose a direct threat to Swedish integrity or territory (Dalsjö, 2010). While this was not a uniquely Swedish development, Sweden made this transition to a greater extent and more swiftly than most of its Nordic neighbours and European partners (SIPRI, 2019).

The solution that came to fill the partly empty security policy space was introduced in the 1990s mainly as new focus areas or activities that security and defence spending would not prioritise, without a new institutional home. Later, new and reformed government agencies were given an increased role, more resources as well as legal measures in the sphere of Swedish security broadly conceived. The intentions and ideas expressed in official Swedish security discourse were clearly directed towards an increased scope of what security is about (or at least how the prioritisation of security dangers is made) as well as a more dispersed institutional structure designed to 
accomplish the security goals of this new era. This has been alternatively labelled societal security, a new version of the Swedish comprehensive security concept including several actors and security concerns simultaneously. ${ }^{2}$ The key component in this new security doctrine guiding Swedish policy for at least 20 years was the deprioritisation of territorial defence as the core component of security policy. However, this doctrine is no longer supported as being sufficient or suitable for the current security climate and Swedish security concerns. There is significant support among major influential actors that a shift towards increased defence spending, more advanced military capabilities, and a greater concern for hostile territorial incursions by Russia have become key aspects of Swedish security policy in the 2010s.

Interestingly, while this quite significant shift in discourse and ongoing concrete change towards increased concern for military security is both obvious and supported by the majority among security elites, it has not replaced or diminished the conceptual understanding of a broad security strategy that continues to govern official security policy. At the same time as attention and resources are designated to purposes pertaining to defending Swedish interests and assets against hostile aggression (in varying shapes and forms), the institutional structure designed to deal with new kinds of security risks and threats, and the conceptual understanding that this wide range of phenomena constitute security problems for Sweden remain.

The developments we may observe in Sweden are possible to identify also in a larger context, across the Nordic region, as well as at the European Union (EU) level (Rieker, 2006; see also Götz and Haggrén, 2009). Current EU practices and policies such as PESCO $^{3}$ and the European Defence Fund (Biscop, 2018) show that the union, after having established internal security cooperation (Boin and Ekengren, 2009; Bossong and Rhinard, 2013), has now taken steps to increase cooperation also on military defence in the EU structure, indicating a convergence or coexistence of both traditional and new emerging security issues simultaneously within the EU system, problematising the external-internal security divide (Duke, 2019). This could be a sign of multiple existing security logics also at the EU level or at least an indication of how our societies aspire to control and deter all sorts of different threats and risks as part of security policy.

If at one point territorial defence and what we could label "traditional security concerns" were the dominating (albeit not the only) security problems relevant for Sweden to address, and the same issue was later reframed as very minor and low risk for a long time following the end of the Cold War, the place we are at now is unique. Either we are in the middle of a shift towards an actual replacing of the broad comprehensive security concept by a new version of the military or hybrid warfare aggression understanding. Or, which I argue is more likely, we are at a place in which distinct and simultaneously present security logics will continue to co-exist, resulting not only in different sets of security policy activities and dangers to address, but also in co-existing and mutually exclusive ways of imagining and engaging 
with security problems. It is presented as vital to Swedish security to increase military capabilities to deter and resist potential Russian attacks. It is also vital to consider new kinds of malevolent agents and the challenges of hybrid warfare as a method used by both conventional and unconventional actors. Additionally, Swedish security is about mitigating and dealing with the effects of climate change, risks connected to technological development and infrastructure, global security issues, environmental problems, international development, and refugee flows. The point is not that these issues per se are new. They are not. It is that the security discourse today lacks a clearly defined focus and is instead fractured and designates all these different phenomena as security problems at the same time.

We need to understand the security politics of our time with an understanding of this complex picture. Security is necessarily more than any one theoretical model can capture from the perspective of elite security officials. One option would be to select a theoretical approach that frames security either as primarily about military threats or as predominantly about societal risks, thereby selecting certain issues as more pressing than others within the security space. Alternatively, however, we could acknowledge an ongoing shift that is redefining and broadening what security policy means, which goes beyond what can be identified by predefining security in particular ways. This chapter sets out to do the latter, by providing an account of these matters from the perspective of the Swedish government, and how it defines threats and risks.

\section{Background}

In the early 1990s, as a response to what was viewed a positive geopolitical development from the Swedish perspective with the Cold War coming to an end, three large processes were initiated relating to Swedish security politics. First, Sweden applied for membership in the EU, which would integrate the country with most of Western Europe and break with the neutrality policy that had been formally in place since the early 1800s (Dalsjö, 2010). Second, the defence forces were to be reduced and rearranged, focusing less on territorial defence and more on security goals in other areas (Agrell, 2016). Third, the objectives of defence and security politics were reconceptualised during this period, partly as a result of the other two processes mentioned here (Westberg, 2015). It was in this context, and to deal with these issues, that the parliamentary defence committees during the 1990s were created, and their reports became important grounds for the defence bills that came to quite radically remake Swedish defence and security politics from a Cold War mode to what was seen as a more modern security politics (Agrell, 2016, pp. 155-157). The process of reaching a consensus in this new space for Swedish national security is ongoing to this day, and we are at a place in which multiple ways of constructing and tackling security challenges are co-existing without any one taking clear primacy (Prime Minister's 
Office, 2017). The government defence bills and the parliamentary defence commission reports have been analysed for the purposes of this chapter. They constitute the major written documents with legal and policy implications that guide the overall security and defence spending and prioritisation from the viewpoint of the Swedish government, essentially speaking also to the public in this way. Furthermore, they are regular and ongoing processes resulting in and representing the evolving changes that this chapter is interested in. In addition, a couple of public inquiry reports on security and defence issued conducted on behalf of the ministry of defence are also included in the empirical material.

What has happened in Swedish security policy has been processes of transformation from one military-centric total defence concept, where all of society were involved in the quest for national security, though under the primacy of military defence and the defence forces as the dominant actor, to a very different - however in language terms similarly sounding - concept of "new" total defence. The idea has progressed from a previous divergent notion of identifying and dealing with all kinds of security issues in different fields - development, energy, global stability, environment, economic, social - where the military and traditional aspects of national security were de-prioritised in the 1990s and early 2000s, to a situation now in which also the latter aspect has grown in importance again, but alongside the quite broadened security conception that has been advanced for many years (see Agrell, 2016; Westberg, 2015).

Sweden's security, and consequently our national interests, are currently impacted by a large number of factors. These involve both new and more traditional threats, and immediate and long-term risks. The careful examination of these factors and strengthening our abilities to prevent, warn of, withstand and tackle the challenges that they generate form an important part of our security efforts.

(Prime Minister's Office, 2017, p. 17)

The security strategy quoted above consciously identifies both threats and risks as security problems, forming a comprehensive - yet complex understanding of security. It continues, "While the benefits of digitalisation are welcome, it is clear that the risks and threats with which it is associated are some of the most complex security challenges that we face" (Prime Minister's Office, 2017, p. 18). Interestingly, both threat and risks are drawn on in these accounts, and a distinction is portrayed between traditional security problems and other types of problems (security risks), where the latter can be of both short- and long term nature. Additionally, the goal for Swedish security - that which shall be sought for security to be had includes both preventive and reactive measures. Not only is it important to act before-hand to mitigate and absorb effects of security problems. There is also a need to actively engage with the environment that is generated as a result of the complex security dangers faced. 
Moreover, the shift in Swedish security discourse since the end of the Cold War reflects how a significant broadening of security has taken place at the same time as a military-territorial logic has resurfaced in recent years, in connection with the geopolitical developments in 2014 (see Agrell, 2016). This makes it clear that we are not dealing with one or the other, not broadened non-military security or primarily a traditional perspective, but rather both logics simultaneously put at the forefront of government security policy.

\section{The conceptual intersection of risks and threats}

With the help of the risk concept, we can explore how security dangers can be categorised as risks alongside the threat security logic (Hammerstad and Boas, 2015). The famous concept of the risk society came to the fore through Ulrich Beck, in explaining how increasingly complex problems emerge and are addressed as political problems for governments. Technological development and the conditions of globalisation bring about risks created by our own very existence and ways of living (Beck, 1992). Managing and calculating risks, the notion of precaution of risks, and the role of security technologies have become dominating features of political life (Aradau and van Munster, 2007). Security policy also works through technology, in how digitalisation and data are employed in risk governance. By collecting and analysing the "digital footprints", the politics of risk security

acts not primarily to prevent the playing out of a particular course of events on the basis of past data tracked forward into probable futures but to preempt an unfolding and emergent event in relation to an array of possible projected futures.

(Amoore, 2013, p. 9)

In this reading, risk and risk discourses constitute one dominating mode of governance, where representations of risk and uncertainty are used to engage and shape our world (ibid., p. 7; see also Liebetrau, this volume).

Within the constructivist school of international relations (see Adler, 2013), the concept of securitisation became influential as a mode of analysis for threat construction. Initially formulated by Wæver (1995), securitisation allows for both a deepening and a broadening (Buzan and Hansen, 2009) of what threats to security can be. Securitisation studies demonstrate how governments construct phenomena as existential threats to certain values and show how that enables political action (Buzan et al., 1998). Corry (2012, pp. 237-238) argues that "riskification", in contrast to securitisation, does not revolve around existential dimensions of security. Risks differ from threats in not operating with the same degree of immediacy and directness. Instead of enabling certain emergency measures, riskification points to measures that need to be taken for politics to manage them in the long run, 
pre-emptively (ibid., pp. 244-245), suggesting a different temporality from a threat logic. The risk logic builds on the goal of taking actions to govern the conditions of possibility rather than defending a specific value or object. Riskification functions through governing the inherent vulnerabilities of danger (Corry, 2012, pp. 246-248). Williams (2008, p. 68) proposes that societal values rather than risk-governance capacities constitute that which is to be protected from the effects of the risks, and present risk security in the following way:

Threats are finite because they emanate from a specific actor, with a limited amount of resources to support capabilities. Risks are infinite. Since risks are only possible scenarios-devoid of any 'real' capabilities - they can exist to a far greater extent than threats. Furthermore, as the 'boomerang effect' notes, in managing a future risk, new risks proliferate. Risk management is a never-ending process - it is about living with insecurity, not providing security through deterrence of the threat from an outside actor, as was the case in the Cold War. The problem is that unlike a threat-based system, where obvious capabilities and intent make it easier for policy-makers to determine where threats lie, a risk-based mindset means that policy-makers must act with far less information to go on

(Williams, 2008, p. 66)

Based on the theoretical propositions presented, Table 10.1 represents crudely the components belonging to different ways of imagining and constructing security.

Four categories or factors for understanding security as threat-driven or risk-based ideal types are used to guide the focus and analysis of the empirical analysis. The nature of security dangers is one characteristic important to understanding the constructing of security. It concerns how security dangers are defined, what is known about them, and how they are constituted (Beck, 1992; Vaughan-Williams, 2015). Agency and intention behind security dangers is another relevant dimension that is used to explore the material. It has to do with what kind of agency and intentionality that are underlying and driving the security dangers (Corry, 2012; Williams, 2008). A third category that helps guide the analysis has to do with the degree to which the security issues are predictable or unknown in terms of how and when they could materialise (Amoore, 2013). Lastly, the way in which politics is proposed to mobilise in order to respond to the security problems i.e. reactive or pre-emptive efforts - is a fourth category that is important for analysing the material from the point of view of risk and threat logics of security (Aradau and van Munster, 2007; Corry, 2012). These four categories for analysing the material are present in the empirical presentation beginning in the next section. 
Table 10.1 Different security logics and their characteristics

\begin{tabular}{|c|c|c|c|c|}
\hline & $\begin{array}{l}\text { Properties } \\
\text { of security } \\
\text { concept }\end{array}$ & $\begin{array}{l}\text { Language of } \\
\text { security }\end{array}$ & $\begin{array}{l}\text { Policies and } \\
\text { practices }\end{array}$ & Political implications \\
\hline $\begin{array}{l}\text { Threat } \\
\text { Logic of } \\
\text { Security }\end{array}$ & $\begin{array}{l}\text { Security } \\
\text { dangers } \\
\text { that happen } \\
\text { (or might } \\
\text { happen) } \\
\text { and come } \\
\text { to endanger } \\
\text { political/ } \\
\text { societal } \\
\text { values and } \\
\text { objects } \\
\text { that need } \\
\text { protection }\end{array}$ & $\begin{array}{l}\text { Identification } \\
\text { of source } \\
\text { of danger, } \\
\text { potential } \\
\text { intentionality, } \\
\text { spatially and } \\
\text { temporally } \\
\text { delimited } \\
\text { danger that } \\
\text { requires } \\
\text { urgent } \\
\text { measures }\end{array}$ & $\begin{array}{l}\text { Enactment and } \\
\text { implementation } \\
\text { of directed } \\
\text { security efforts } \\
\text { to eliminate } \\
\text { or mitigate } \\
\text { specified } \\
\text { security } \\
\text { problems }\end{array}$ & $\begin{array}{l}\text { Legitimacy for } \\
\text { governments to take } \\
\text { new and possibly } \\
\text { "exceptional" } \\
\text { measures and use } \\
\text { of technology. } \\
\text { Relation between } \\
\text { state and citizen }\end{array}$ \\
\hline $\begin{array}{l}\text { Risk } \\
\text { Logic of } \\
\text { Security }\end{array}$ & $\begin{array}{l}\text { Potential and } \\
\text { possibilities } \\
\text { of security } \\
\text { problems } \\
\text { that could } \\
\text { occur in } \\
\text { the future, } \\
\text { thereby } \\
\text { possibly } \\
\text { causing } \\
\text { harm to } \\
\text { political/ } \\
\text { social } \\
\text { values and } \\
\text { functions }\end{array}$ & $\begin{array}{l}\text { Knowledge } \\
\text { claims about } \\
\text { potential } \\
\text { security } \\
\text { dangers } \\
\text { that might } \\
\text { materialise at } \\
\text { some point. } \\
\text { Uncertainty } \\
\text { in terms of } \\
\text { concrete actor } \\
\text { and time. } \\
\text { Pre-emptive } \\
\text { actions } \\
\text { necessary } \\
\text { to reduce } \\
\text { potential for } \\
\text { damage }\end{array}$ & $\begin{array}{l}\text { Pre-emptive } \\
\text { policies and } \\
\text { practices } \\
\text { designed to } \\
\text { reduce the } \\
\text { likelihood } \\
\text { and impact of } \\
\text { potential and } \\
\text { vague security } \\
\text { dangers which } \\
\text { might - and } \\
\text { might not - } \\
\text { materialise } \\
\text { concerning } \\
\text { specified sectors }\end{array}$ & $\begin{array}{l}\text { Acknowledgement } \\
\text { of lack of control, } \\
\text { living with } \\
\text { uncertainty in a } \\
\text { state of security } \\
\text { problems which } \\
\text { could harm us } \\
\text { and which we try } \\
\text { to manage, with } \\
\text { uncertain outcomes. } \\
\text { Affects relations } \\
\text { among individuals } \\
\text { and groups as well } \\
\text { as those between } \\
\text { individuals and } \\
\text { political power } \\
\text { structures }\end{array}$ \\
\hline
\end{tabular}

Inspired from Corry (2012) and Williams (2008).

\section{Swedish national security: risks, threats, and uncertainties}

The chapter proceeds in two parts. This first part addresses specifically the Swedish security context during its institutional time of transition from a Cold War structure to one in which military security was significantly deprioritised in favour of other security problems. ${ }^{4}$ This includes also account of the official Swedish security policy during the 2000s, in which much of this transition was finalised. The second part addresses the recent years with a focus on the increased relevance again for territorial security in the new European security context. 
Although the empirical material examined in this chapter stems primarily from the policy area of defence, as I will show, the material uses the broader security concept that goes well beyond military security, and deals with threats and risks within policy areas concerning both justice and home affairs as well as climate and environment. One result of the defence commission reports and defence bills during the last decades has been to include in the policy area of defence security problems of very different types. The institutional structures of defence commissions and defence bill processes have been used as vehicles for politically transforming defence policy from the traditional Cold War understanding to a much broader and more complex idea of security politics. It should be said, however, that not all aspects concerning security in the wide sense are included in this material. The material presented here represents the most central widespread understandings of the most important challenges to Swedish security. The material will allow us to see what the broadening and deepening of security has come to mean in Swedish politics, both in terms of the phenomena denoted as security problems and in terms of the expansion of the policy field of defence politics to include these dangers.

The first defence commission in its present form was initiated by the Swedish government in 1992, to facilitate and seek consensus for reforms in Swedish security and defence policy after the Cold War (Agrell, 2016, pp. 93-94). The first comprehensive defence bill to begin to implement a shift (ibid., 2016, p. 140) was presented to the Swedish parliament in September 1995. There was a clear and open recognition that the security environment as such has indeed undergone significant change and that security must be understood as a broader concept. It explains how old threats have been eliminated or reduced, transforming the security politics to now dealing with new risks and challenges that have emerged (Prop. 1995/96:12, p. 2). The change was evident also concerning civilian societal safety issues, in talking about the broadening of security, and new risks and uncertainty emanating from societal change, technological change, and complexity (SOU 1995:19, p. 57).

The understanding of the time was that global developments were transformative, which necessitated adaptation from public governance functions to adapt military and civilian resources to better achieve societal safety and security. The definitions of threats and risks offered are that whereas the latter is concerned with probability for something undesired to happen, a threat is imminent and represented by a concrete actor or a chain of events that - if not stopped - will bring harm (SOU 1995, p. 65-66). It is noteworthy that the defence bill from 1992 was overtly positioned in relation to issues of possible concrete attacks or territorial incursions, where a military reactive logic was the dominating means to deal with that possibility. Although a changing security environment was recognised, the bill nevertheless corresponds very much to a traditional threat-based logic ideal of a view of security (Prop. 1991/92:102, pp. 4, 8-9). This shows that the transformative 
process instigated by the new defence commission process and the resulting policy changes were designed to point to a new way of imagining security and defence.

The purpose of the 1995 total defence bill was to address a context in which security politics must be holistic, dealing with military security problems as well as non-military threats and risks (Prop. 1995/96:12, p. 4). While the military perspective is still present and important, the bill also emphasises how the new security climate is more unpredictable, and that it needs to be watched closely, for security politics to be able to adapt to new conditions (ibid., p. 6). The bill explicitly designates several security problems as not being military threats, but which nevertheless constitute security problems that this bill serves to enable agencies to combat (ibid., p. 8). Denoting broadened security as a guiding concept, it is clear that the government wants to promote a different way of conceiving security, one that includes military threats, the uncertainties concerning global development, the vulnerabilities inherent in modern societies, and the risks that they might be connected to (ibid., p. 29-30).

A holistic view of security where military and civilian agencies are required to tackle security issues was also present in the preceding report from the parliamentary defence commission in May 1995, which emphasised how financial flows, technological developments, and social and economic tensions are all relevant factors for security politics broadly (Ds 1995:28, p. 111). The interface between technologies, vulnerabilities, and natural disasters as well as hostile acts are described as new types of risks and threats (ibid., p. 112).

The role of the armed forces and a traditional threat perspective remains important, but merely represents some out of many other equally important aspects of security in this time (Ds 1995:51, p. 37). It is acknowledged without making any meaningful distinction between the two concepts that "dealing with all threats and risks necessitates a degree of balancing between pre-emptive measures and actions to deal with incidents as they occur" (ibid., 41, my translation). The continued relevance of broadened security issues and associated ideas during the second half of the 1990s is displayed in Table 10.2, following the policy change the preceding years.

At the end of the 20th century, it has been made abundantly clear that the security environment has undergone a major change since the end of the Cold War, and that this has implications for Swedish - and indeed, European - security. At the same that what we can call the geopolitical security context, that is relations between states, has improved and the outbreak of war in Sweden is deemed highly unlikely, the uncertainties in this new context are many and impossible to control. While security comes to take on properties that go well beyond military operations and wartime scenarios, the same uncertainties and new risks and threats that become politically incorporated in the field of security politics may give rise to situations and effects that in the unknown future come to worsen the overall security 
Table 10.2 Threats and risks in Swedish security discourse 1996-1999

\begin{tabular}{|c|c|}
\hline Source & Threats and risks, context, and actors \\
\hline Ds $1996: 51$, pp. $34-35$ & $\begin{array}{l}\text { Military conflicts, supply crises, ecological } \\
\text { imbalances, mass migration, nationalism, } \\
\text { ethnical and cultural conflicts, terrorism, } \\
\text { interdependencies and complexities in } \\
\text { modern societal functions, technologies, and } \\
\text { infrastructure, non-state actors, intra-state } \\
\text { conflicts, WMDs. }\end{array}$ \\
\hline $\begin{array}{l}\text { Prop. } 1996 / 97: 4, \text { pp. } 13,20 \text {, } \\
\quad 52-53\end{array}$ & $\begin{array}{l}\text { Uncertainty, readiness for military security } \\
\text { issues, international crime, environmental } \\
\text { incidents, international humanitarian crises, } \\
\text { inherent societal vulnerabilities. }\end{array}$ \\
\hline Ds $1998: 9$, pp. 102-103 & $\begin{array}{l}\text { Technological dependencies, intra-state } \\
\text { war, non-state actors, changing nature of } \\
\text { military force, new means to conduct war and } \\
\text { military operations, new technologies, military } \\
\text { resources and strategies, precision weapons, } \\
\text { small military units. }\end{array}$ \\
\hline Ds 1998:9, pp. 104-107 & $\begin{array}{l}\text { Societal functions, international dependencies, } \\
\text { information security. }\end{array}$ \\
\hline Ds 1998:9, p. 109 & $\begin{array}{l}\text { The internet in relation to international criminal } \\
\text { networks and terrorism. }\end{array}$ \\
\hline Ds 1998:9, p. 132 & $\begin{array}{l}\text { Conflicts between nations and groups, social and } \\
\text { economic inequalities, mass unemployment, } \\
\text { extremist movements, pollution, raw material } \\
\text { shortages, complex connections, unpredictable } \\
\text { security context. }\end{array}$ \\
\hline Ds $1999: 2$, pp. $84-86$ & $\begin{array}{l}\text { Traditional military and new security problems } \\
\text { resulting from technological development, } \\
\text { modernity, complexity, societal vulnerability. } \\
\text { Increasing robustness, acting against dangers } \\
\text { that affect society at large or many individuals } \\
\text { prioritised. }\end{array}$ \\
\hline Ds $1999: 55$, pp. 59, 89-90 & $\begin{array}{l}\text { Traditional security readiness against potential } \\
\text { military attacks. Importance of broadening } \\
\text { security, comprehensive security, civil defence, } \\
\text { securing societal functions, dealing with } \\
\text { vulnerabilities. }\end{array}$ \\
\hline Prop. 1999/2000:30, p. 31 & $\begin{array}{l}\text { Swift and limited military armed attack, } \\
\text { attacker that is difficult to identify new forms } \\
\text { of coercion, information systems, non-state } \\
\text { actors, advanced and non-conventional } \\
\text { weapons, severe societal stresses. }\end{array}$ \\
\hline
\end{tabular}

environment. This tells us two things. First, it becomes obvious that security politics came to incorporate military security awareness and preparedness as well as an expansionist broadening of security during and through this transformation. Second, the reports and defence bills collectively recogniseand demand - the need for continuing assessments and reassessments of the security situation from this new broad perspective. That means that 
there was never a complete shift from one way of thinking and doing security to something else, in the sense that both approaches remained present. But there was clearly a shift in the sense that the shapes and forms of security problems were recognised to have expanded to include numerous complicated phenomena that were not - and could not - be the domain of the defence forces. In that way, security politics was indeed reconceptualised substantially by elite politicians and the Swedish government during the 1990s. Security problems could emanate domestically as well as in distant places. Some problems directly endangered the security of individuals, whereas others primarily concerned societal functions or the environment. Some security problems were to be dealt with via direct measures, after having been delimited, identified, and concretely present in some form. This concerned mainly military security problems. Others were vaguer in nature, not yet having become manifest, and yet were identified as potential future sources of security problems that should be pre-emptively worked against, speaking to the threat/risk distinction.

It is obvious from these texts that the authors did not attach fundamental distinctions to the terms threat and risk, and often times did use them interchangeably. However, it is equally clear that the two different security logics - as ideal types - that lie at the basis for this study can be identified as simultaneously present in these texts. By expanding security to include so much, it becomes difficult even for the most ambitious government to pretend that it can actively and at all times take action against all security challenges that exist. It by necessity becomes a matter of analysis, control, selection, and - for certain issues - pre-emptive measures.

The scope of security politics has substantially broadened, covering many different areas and political sectors. It cannot be fixed, and the area instead must be continuously analysed and the capabilities and responses adapted. Concerning the nature of security dangers, those that concern military attacks and traditional security dangers are deemed quite few and unlikely, and in that sense then delimited and concretely identified. However, many of the "new" security problems suggested are associated with much more complexity and cannot be easily identified or traced to some specific source. The picture is similar regarding agency and intentionality behind security dangers. Some states, organisations, and groups are denoted intentions and agenda to influence Sweden in negative ways through different means, whereas other security problems are open and not associated with agency. The time and space perspectives have overall been quite unspecific, and no security danger has been specified to occurring at one specific point in time or at a particular place. What is interesting, however, is the distinction being made between some phenomena that are imagined needing to be dealt with swiftly and immediately as they occur, and other problems that are better addressed by strengthening societal robustness at home and pre-empting conflicts abroad. This "dual approach" to security represents an obvious shift from a Cold War military logic to a much more open, flexible, and complex security understanding, with a comprehensive, broad, and riskinfluenced component making out one of the two legs. 
During the 2000s, the same development was to a large extent affirmed, almost to the point of constituting a security paradigm of comprehensive security policy. The same type of documents for the years 2001-2009 and how they emphasise partly new issues following the established view of security since the start of the transformation process in 1995 are summarised in Table 10.3.

Table 10.3 Threats and risks in Swedish security discourse 2001-2009

\begin{tabular}{|c|c|}
\hline Source & Threats and risks, context and actors \\
\hline $\begin{array}{l}\text { Ds } 2001: 14, \text { pp. } 115,177 \text {, } \\
\text { 212-213 }\end{array}$ & $\begin{array}{l}\text { Local and regional conflicts abroad, international } \\
\text { crises and conflicts, pre-emption of conflicts } \\
\text { abroad also for Swedish security. Direct, } \\
\text { intentional attacks against electricity, } \\
\text { information and communications systems. }\end{array}$ \\
\hline Ds $2001: 44$, pp. $68-69$ & Telecommunications, electricity, and information \\
\hline SOU 2001:41, p. 185 & $\begin{array}{l}\text { technologies vulnerable to different security } \\
\text { dangers, intentional and otherwise. Both pre- } \\
\text { emptive and direct action. }\end{array}$ \\
\hline Ds 2001:44, p. 30 & Improving resilience of technical infrastructure to \\
\hline Ds 2001:14, p. 113 & resist vulnerabilities and intentional attacks. \\
\hline Prop. 2001/02:10, p. 11 & $\begin{array}{l}\text { Vulnerability has increased in tandem with } \\
\text { technological development. Growth of new } \\
\text { threats and risks. Unpredictable security issues. } \\
\text { Military threats as well as other threats and } \\
\text { risks, in peace and war. }\end{array}$ \\
\hline Ds $2003: 8$, pp. $48-49$ & $\begin{array}{l}\text { Increased focus on terrorism: complex problem } \\
\text { requires international collaboration, a threat } \\
\text { as well as a risk. Shift from direct threats to } \\
\text { inherent risks. }\end{array}$ \\
\hline Ds $2003: 34$, pp. $20,27-28$ & $\begin{array}{l}\text { Terrorism, non-state actors, information } \\
\text { technology, WMDs, vulnerabilities in } \\
\text { infrastructure and moderns societies. Long-term } \\
\text { international political developments, climate } \\
\text { change, and acute situations connected. }\end{array}$ \\
\hline Ds 2004:30, pp. 42-43 & $\begin{array}{l}\text { Connection between political oppression, socio- } \\
\text { economic conditions, ethnic and religious } \\
\text { tensions, and terrorism. }\end{array}$ \\
\hline Prop. 2004/05:5, p. 31 & $\begin{array}{l}\text { Military resources, military security one } \\
\text { important part of the security concept. }\end{array}$ \\
\hline Ds 2006:1, pp. 17-18 & $\begin{array}{l}\text { Inherent unpredictability and uncertainty of } \\
\text { security dangers, constant process of change. } \\
\text { Reducing inherent vulnerabilities, preventive } \\
\text { measures, long-term pre-emption of climate } \\
\text { change and poverty important. }\end{array}$ \\
\hline Ds $2007: 46$, pp. $15-19$ & $\begin{array}{l}\text { Energy access issues, climate change, natural } \\
\text { disasters, organised crime. }\end{array}$ \\
\hline Prop. 2007/08:92, pp. 7, 55 & $\begin{array}{l}\text { Agency for comprehensive societal safety and crisis } \\
\text { management coordination formed. }\end{array}$ \\
\hline Prop. 2008/09:140, pp. 11-12 & $\begin{array}{l}\text { Deactivated mandatory conscription, new } \\
\text { employment structure, emphasis on Swedish } \\
\text { military at home and abroad, swiftly employed. }\end{array}$ \\
\hline
\end{tabular}


The security developments in Sweden during the first years of the 2000s are very much a continuation - and oversee the actual implementation of the transformative shift in thinking about security that took place the preceding decade. It became increasingly clear that the scope of security could not be confined to any one domain or a few policy areas. Security became instead established as a cross-sectoral concept including even more of transboundary properties. Concerning the set of security dangers identified, they were more specified, and the suggested links between certain phenomena and the implications for security were clarified. This suggests an expansion of a risk security logic, with everything security-related becoming even more complex and uncertain (see also Liebetrau, this volume). This is analogous to what happened concerning the category of intentionality behind security dangers. It is arguably the same broad philosophy of security politics that underlies the texts during both periods, but during the 2000 s the texts are much clearer as to the distinction between intentional and non-intentional security threats, and in acknowledging that both exist and need to be dealt with by security politics. Regarding locating threats and risks temporally and spatially, it is still to a large extent unclear as to how the security dangers are delimited in the texts. However, since the time and space dimensions are discussed more as a general point, including temporal connections between different security-related events and an emphasis on the lessening relevance of borders and the "national" part of security, the security concept evolved a step toward the risk logic during these years. Perhaps most interestingly, the focus on pre-emptive measures to reduce vulnerabilities and possible future security dangers increased during this period. The underlying notion of acting in the present to avoid possible harms in the future connects to the risk logic of security. The threat logic, driven by reactive measures and direct action toward security problems, however, was still present, although to a lesser extent. In summary, after the continued reforms during the 2000s, all the indicators tell us that the uncertain and open risk logic had gained ground in Swedish security thinking, although it is difficult to determine its precise relative weight compared to the threat logic. The important point is that both logics were clearly present, and that security thus had come to include temporal and spatial properties that go beyond traditional conceptions.

\section{3-2017: a new security logic?}

The most recent defence bill ${ }^{5}$ was accepted by the Swedish parliament in 2015 , and it was preceded by two reports from the defence commission that were directed to provide background analyses and recommendations for its content. The 2013 defence commission report and its account of Swedish security, threats, and risks does not differ in any relevant way from the view of security in the 2009 bill, other than the specific way in which they are 
presented. The following quote is presented to illustrate the 2013 security concept:

The threats to our security cross borders and sectors. They can be terrorism, organized crime, disruptions in critical systems and flows, failing states, economic crisis, political and religious extremism, threats to democracy and rule of law, social alienation, migration streams, threats to values, climate change, natural disasters and pandemics, and armed attack. These threats are of varying force and in some cases characteristically highly diverse

(Ds 2013:33, p. 215, my translation)

As is evident, this security concept is arguably as broad as it gets, and the accounts in the report are otherwise similar to the texts from the late 2000s. Much of the content is also similar in the report from May 2014 with one main exception: the Russian annexation of Crimea, following deployment of military personnel, in February the same year. According to the report, it represents a break of the European security order and is an act of aggression that will require a re-evaluation of the security analysis, and the aggression is predicted to have long-term negative consequences for the EU-Russia relationship (Ds 2014:20, pp. 16, 21). Although the overall security threats and risks are similar to previous texts, and that the likelihood of an armed aggression against Sweden is determined to be unlikely, given the close to static condition of the guiding principles for security thinking for many years, this does suggest a significant shift going forward. Cyber security as a concept is given a more important position in this report and is used to describe antagonistic threats to information and communication systems and data storage servers. Not only is security seen to incorporate the functioning of these important services as has previously been established. It is also explicitly described that these systems need safeguarding to prevent vital information from falling into hostile hands, and it is in this context that cyber security becomes important (ibid., pp. 32-33).

Cyber security and the related concept of information warfare or information operations, designed to distract and affect a target through the dissemination of false or misleading information, are presented as central concepts in a challenging security environment in the government's defence bill in 2015 (Prop. 2014/15:109, pp. 40-41). All the previously established long-term security challenges abroad and in the international development are in the bill, but they are not as central as in earlier texts. Noteworthy, among the thematic security threats identified, all are antagonistic security in nature (information warfare, cyber security, terrorism, and weapons of mass destruction) (ibid., pp. 40-41). The only identifiable significant change in the security environment is the Russian aggression towards Ukraine, including Russia supporting irregular Ukrainian forces engaged in fighting with the Ukrainian army. The bill acknowledges that the Russian government made 
use of conventional military assets, unconventional military strategies, and employed information warfare as a complement to the military aggression (ibid., p. 42). One conclusion is that the security situation has deteriorated and become more dangerous as a result of the Russian aggression (ibid., p. 11). Another conclusion is that Sweden must prepare to be affected by hybrid operations involving both conventional means and information warfare employed jointly, and that military aggression can be implemented with varying purposes and ideas (ibid., pp. 46, 55).

The overall threat and risk assessment is similar in the 2017 report from the defence commission compared to the 2014 version. It clarifies that cyber-attacks and information system incidents should be seen as possibly integrated events of an armed conflict and broadly emphasises the importance of digital issues for security. The report also goes further in specifically identifying the terrorist threat as being growing, and represented by radical Islamic, autonomous leftist and right-wing extremist groups (Ds 2017:66, p. 18). The Swedish security strategy presented by the government in January 2017 represents a very clear broad security perspective. All potential security dangers that have previously been accounted for in this chapter are identified, and each one includes a prevention or vulnerability dimension alongside a more active concrete reactive logic (Prime Minister's Office, 2017 pp. 17-25). The threats are both external and internal, and the dependencies on supply flows, access to information, and the complexity associated with unpredictable security dangers make them challenging to control (ibid., pp. 5, 8).

Recognising this complexity and the very broad - and integrated approach to security proposed by the strategy is the recommended way forward from the Swedish government. Military threats make out one category in the strategy while the military component was more prominent in the current defence bill, indicative of that the different texts serve different functions and audiences. If the security strategy represents a recognition of how both ideal-type logics can have a role to play for all identified security dangers, the institutional structure and the consensus-seeking purpose of the defence commission suggests that its reports also represent the political prioritisation of which security challenges are most crucial. From that perspective, we observed that there was indeed a change in priorities in 2014 and 2015, following the Russian aggression against Ukraine. Not only did the defence bill and the defence commission address this as the most influential event in European security in the last 25 years. It was also the most prioritised security problem in those texts. It becomes an especially striking shift in the context of widespread ideas about "permanent peace" having been prevalent with the political leadership only a few years earlier (Westberg, 2015, pp. 203-204). Security is clearly about many different policy areas and domains. There is also still a broad range of different security problems present in the accounts. However, due to the 2014-2015 change, one event (Russia's military aggression) was given a more important 
position, bringing with it a slight delimitation of the security configuration. The focus on military aggression, terrorism, and cyber security attacks also suggests a shift toward an increased focus on intentional agents behind security dangers compared with the 2000s. There is no meaningful change concerning the time and space category. Security threats and risks remain elusive and unpredictable. The responses to security dangers are mixed and constituted by aspects from both security logics: pre-emption, resilience building, and swift reactive responses, depending on the nature of the situation and event. In sum, this demonstrates how the threat logic has become more present (again) during the last years, but given the widespread cohabitation with risk security, the picture is complicated. For instance, the focus on military force in 2014-2015 represents means (armed aggression) which are associated with the ideal-type threat logic, but where the conduct (resources, strategy, operations) are complex and partly associated with an ideal-type risk logic.

In order to get a better grasp of where we are and which ideas and underlying purposes that control what is going on, we would need to know more about the actual policies that are implemented and with what aims and implications. Based on the presentation in this chapter, the following security problems have been identified as the most important found in the texts: military aggression by a state, terrorism acts, cyber security and information attacks, migration flows, climate change and environmental disasters, diseases and pandemics, local and regional instability abroad, technical infrastructure and communication problems, and supply shortages of resources and energy. Judging from the last defence bill and defence commission report, the first three are presently the most emphasised security dangers. The return to territorial defence as a primary security issue since 2014 is consistent with the post-Crimea arguments of a return to geopolitical concerns for Europe and the US (Mead, 2014). This is consistent also with the arguments about a return to geopolitical considerations, or at least a revival of them, following 2014, which has meant a re-emphasis on territorial security in Europe (Raik, 2019). Broad, emerging security challenges going far beyond territorial security were if not a paradigm at least an assumption in parts of the field (Swain, 2013) which is now complicated in the Swedish case both by scholarly arguments about the return to territoriality, not least in the Nordic region (Åtland, 2016), and by the mixed empirical picture presented here. There is a dual or twofold structure in place, consciously, or otherwise designed in such a way, which includes security policies and actors focusing on both conventional threats and emerging risks of different sorts. This means that there is not one overall security logic or paradigm at work as we understand it.

\section{Conclusion: towards a new security paradigm?}

The findings result in three trends of relevance for Swedish security policy. First, there has been an expansion in the types of phenomena being 
named as problems of security, relating to different policy areas. Second, it is striking to observe how security has become a goal and a problem for politics at large, from previously having been primarily attached to the defence sector. Third, risk language has made inroads in the security discourse, progressively over the years, alongside the still prioritised threat language. This is particularly the case for technical infrastructure matters and general developments abroad, whereas cyber security and certain aspects of military security retain properties connected with the threat logic. Indeed, what complicates the picture is that this change towards broadened security and a risk conceptualisation has happened while at the same time traditional security ideas have remained important as well. We therefore have to deal with an empirical context that has not "evolved" from one mode of security to something else. It is rather the case that we can see a broadening and deepening of security, including conceptualisations in terms of risk and a way of "doing" security which has to do with climate-related security challenges, technological vulnerabilities, global patterns of mobility, and the risk of terrorist acts.

Based on these results, it can be concluded, on the one hand, that traditional security thinking is still prevalent as one main logic for how national security politics pursues threats and risks. That we have a more complicated picture today does not mean that we should disregard the existential (albeit low risk) dangers to territorial integrity and national sovereignty. Granted, no other identified security problem than military aggression is recognised as having the potential to imminently endanger the continued existence of the Swedish state. However, the emphasis here must be placed on the "imminently" part, since many risks that are defined can surely be seen as severely threatening or putting at risk the functioning of Sweden as a political entity and the well-being of its population, although not in a clearly identifiable way and immediate sense.

On the other hand, the chapter has shown that Swedish security politics has changed to incorporate a risk logic alongside a threat logic, leading to an increase in risk security in the national security thinking in Sweden. While security policy is clearly about territorial security and national sovereignty through military means and resources, it is about much more than that. It is about economic, societal, and health security as well. It takes the shape of risk in addressing the always non-fixed nature of security problems and the possible consequences of climate change, natural disasters, potential terrorists, and technological disruptions. It recognises how many of the risks that endanger Swedish security can never be controlled or indeed even completely identified, and suggests a way of thinking about, living with, and dealing with security that is existentially distinct from how we politically relate to defence planning issues. It shows that security politics has taken on properties that do not operate according to the assumed principles of traditional security, with clearly identifiable threats that can be eliminated and society thereafter resuming "normalcy" before the next acute problem arises. We can instead see how security politics in part is configured in terms 
of a continuous state of managing potential and uncertain security problems of different types across several policy sectors, in the name of security.

If the concept of risk in security politics during the Cold War was instrumentally deployed as a means of assessing probabilities of adversaries taking action - particularly concerning nuclear weapons - and attempting to estimate the consequences of those actions (Lundgren, 2013), risk security in the sense that it is employed here suggests a more opaque logic. Today, risk security would seem to encompass generally harmful events, military and otherwise. This shows how the concept of security has more layers now than retrospective understandings of Cold War security included. The risk concept is more a way of thinking about and "doing" security, rather than as an instrument for assessing the likelihood of something happening.

The security apparatus now consists of multiple actors, technologies, and mandates assigned to dealing with a complex range of issues, which break down many of the conceptual distinctions that have previously upheld security policy as such, but also the two separate logics employed in this chapter. We are dealing with external threats as well as with internal risks, with intentional hostile agents as well as non-agent-based dangers, with state actors and non-state actors, with military as well as non-military, with identified actors and non-identifiable agents, with threats that are concrete and taking place in a physical space, and with risks that can take place on unknown multiple locations, or in cyberspace, all with varying degrees of predictability. Risk security, in other words, increasingly targets individuals or groups, as either potential dangers or objects of protection, "inside" the realm of governance. However, at the same time, traditional policies related to more or less concrete and war-related threats from the "outside" of the state have remained in place or been only temporarily supressed. The implications from this suggest that governments will engage with an obscure security environment, where they claim to be addressing all kinds of risks and threats, but where ultimately priorities will be made which privileges some concerns over others, through decision-making processes deserving of public scrutiny.

Policy priorities related to Swedish total defence that became taken off the agenda after the Cold War have resurfaced or been re-established with, in some cases, only slight adjustments and updates. Indeed, new risks, old threats, as well as hybrid and in-between phenomena are now supposed to be handled by what can be referred to as a "total defence 2.0"; that is, a "holistic" apparatus covering a spectrum of dangers, antagonistic forces, and suspicious individuals, a system for targeting a multiplicity of both threats and risks - without conflating them into one and the same. It can be concluded, therefore, that Swedish security policy today is rendered by a logic and rationale that is not entirely open-ended, nor strictly dichotomous, but if anything, dual and twofold. What was once understood as "total" in the traditional, Cold War era model of Swedish "total defence" has in a sense taken on a new, expanded, and far more complex meaning. 
"Total" does no longer refer to mobilising the different branches of domestic defence, but rather refers to how virtually all societal phenomena may be considered "dangerous" and therefore a potential "security matter" to be handled by a "security professional" and sorted into frameworks for risk management or threat mitigation.

Security politics have, in a way, become the new "normal politics" today, in the sense that almost all policy areas in different ways have come to relate to - that is, support or undermine - the constitution of, planning for, and operation of both societal and territorial forms of security. Territorial security did not turn to societal security after the Cold War, and societal security did not return to territorial security after 2014. Perhaps, with the duality and twofold-ness of contemporary security work, the total defence 2.0 model that is presently being planned in Sweden may signify an emerging form of "socio-territorial security".

Broader issues of concern for security studies that we need to know more about relate to the prevalence and co-existence of threat and risk logics in other settings. To what extent have similar developments and "returns" to territorial logics unfolded in the rest of the Nordic region? How have other Nordic governments responded to the Swedish (re)turn to defence thinking? With the coalescence of EU member states around new forms of European defence cooperation, how does this affect the dynamics and solidarities within the Nordic "community"? The shifts observed in this chapter indeed problematise what "Nordic security" means and does, and point towards the need for continued critical attention towards the evolution of security policies, not only in Sweden, but across the Nordic region and the rest of Europe.

\section{Notes}

1 The ministry of defence is the branch of the Government Offices of Sweden formally behind all released government bills, defence commission reports, and the public inquiry reports related to security and defence issues that are included as empirical material in this chapter. However, the content of the defence commission and the public inquiry reports are not the same as the view of the ministry of defence or the government. For reasons of clarity and in order to separate between the different empirical documents cited, the empirical material from the ministry of defence is consistently cited in-text by their designated document type and registry number in the public records in addition to the year it was published. "Ds 2017:66" refers to a document (departementsskrivelse) published by the Government Offices of Sweden in 2017, and 66 identifies the specific document. In this chapter, all sources of this type are defence commission reports. Cites that refer to "Prop." followed by the parliamentary year in which it was published (i.e. 2000/2001, which covers the period between the opening of parliament in September each year, lasting well into the following year) and a number refer to a government bill (proposition) and their specific registry number. Lastly, cites that begin with "SOU" refer to a public inquiry report (Statens Offentliga Utredningar). All sources are found in the reference list, in which the in-text citation information is found in the title of each document. 
2 See also Larsson (this volume).

3 Permanent Structured Cooperation.

4 This chapter serves as an important complement to Larsson's reading of the post-Cold War reform period in Sweden, since it focuses not on tracing the socio-historical production of security knowledge and authority at the bureaucratic and agency level, but rather on mapping in detail the discursive shifts in security policy at the parliamentary and governmental level.

5 A New defence bill is expected to be proposed from the government to the Swedish parliament in late 2020 .

\section{References}

Adler, E. (2013) 'Constructivism in International Relations: Sources, Contributions, and Debates' in Carlsnaes, W., Risse, T. and Simmons, B.A. (eds.) Handbook of International Relations. London: Sage, pp. 112-144.

Agrell, W. (2016) Det säkra landet?: Svensk försvars-och säkerhetspolitik från ett kallt krig till ett annat. Stockholm: Gleerups.

Amoore, L. (2013) The Politics of Possibility: Risk and Security Beyond Probability. Durham, NC: Duke University Press.

Aradau, C. \& van Munster, R. (2007) 'Governing Terrorism through Risk: Taking Precautions, (un)Knowing the Future', European Journal of International Relations, 13(1), pp. 89-115. Available at: doi:10.1177/1354066107074290 (Accessed: 18 December 2019).

Åtland, K. (2016) 'North European Security after the Ukraine Conflict', Defence \& Security Analysis, 32(2), pp. 163-176. Available at: doi:10.1080/14751798.2016.1160 484 (Accessed 19 December 2019).

Beck, U. (1992) Risk Society: Towards a New Modernity. London: Sage.

Biscop, S. (2018) 'European Defence: Give PESCO a Chance', Survival-Global Politics and Strategy, 60(3), pp. 161-180. Available at: doi:10.1080/00396338.2018.1470 771 (Accessed: 18 December 2019).

Boin, A. \& Ekengren, M. (2009) 'Preparing for the World Risk Society: Towards a New Security Paradigm for the European Union', Journal of Contingencies and Crisis Management, 17(4), pp. 285-294. Available at: doi:10.1111/j.14685973.2009.00583.x (Accessed: 18 December 2019).

Bossong, R. \& Rhinard, M. (2013) 'The EU Internal Security Strategy: Towards a More Coherent Approach to EU Security', Studia Diplomatica, 66(2), pp. 45-58.

Buzan, B., Wæver, O., \& de Wilde, J. (1998) Security: A New Framework for Analysis. Boulder, CO: Lynne Rienner.

Buzan, B. \& Hansen, L. (2009) The Evolution of International Security Studies. New York: Cambridge University Press.

Corry, O. (2012) 'Securitisation and 'Riskification': Second-Order Security and the Politics of Climate Change', Millenium - Journal of International Studies, 40(2), pp. 235-258. Available at: doi:10.1177/0305829811419444 (Accessed: 18 December 2019).

Dalsjö, R. (2010) 'Från neutralitet till solidaritet: Omgestaltningen av Sveriges säkerhetspolitik efter det kalla kriget', in Engelbrekt, K. and Ångström, J. (eds.) Svensk säkerhetspolitik $i$ Europa och världen. Stockholm: Norstedts juridik, pp. 61-80.

Duke, S.W. (2019) "The Competing Logics of EU Security Cooperation". Survival: Global Politics and Strategy, 61(2), pp. 123-142. Available at: doi:10.1080/00396338 .2019.1589092 (Accessed: 18 December 2019). 
Götz, N. \& Haggrén, H. (2009) 'Introduction: Transnational Nordic Alignment in Stormy Waters,' in Götz, N. and Haggrén, H. (eds.) Regional Cooperation and International Organizations: The Nordic Model in Transnational Alignment. New York: Routledge, pp. 1-22.

Hammerstad, A. \& Boas, I. (2015) 'National Security Risks? Uncertainty, Austerity and Other Logics of Risk in the UK Government's National Security Strategy', Cooperation and Conflict, 50(4), pp. 475-491. Available at: doi:10.1177/0010836714558637 (Accessed: 18 December 2019).

Lundgren, C. (2013) "What Are the Odds? - Assessing the Probabilities of a Nuclear War", The Nonproliferation Review, 20(2). Available at: doi:10.1080/10736700.2013 .799828 (Accessed: 18 December 2019).

Mead, W.R. (2014) 'The Return of Geopolitics: The Revenge of the Revisionist Powers'. Foreign Affairs, 93(3), pp. 69-79.

Raik, K. (2019) 'The Ukraine Crisis as a Conflict over Europe's Political, Economic and Security Order', Geopolitics 24(1), pp. 51-70. Available at: doi:10.1080/146500 45.2017.1414046 (Accessed 19 December 2019).

Rieker, P. (2006) Europeanization of National Security Identity - The EU and the Changing Security Identities of the Nordic States. New York: Routledge.

Stockholm International Peace Research Institute (SIPRI) (2019) 'SIPRI Military Expenditure Database', SIPRI 2019 [online]. Available at: www.sipri.org/ databases/milex (Accessed 6 June 2019).

Sveriges Television (2015) 'ÖB: Försvarsuppgörelsen räcker inte', Sveriges Television, 28 April [online]. Available at: www.svt.se/nyheter/inrikes/obforsvarsuppgorelsen-racker-inte (Accessed 6 June 2019).

Swain, A. (2013) Understanding Emerging Security Challenges: Threats and Opportunities. New York: Routledge.

Vaughan-Williams, N. (2015) Europe's Border Crisis: Biopolitical Security and Beyond. Oxford: Oxford University Press.

Wæver, O. (1995) 'Securitization and Desecuritization' in Lipschutz, N. (ed.) On Security. New York: Columbia University Press, pp. 46-87.

Westberg, J. (2015) Svenska säkerhetsstrategier 1814-2014. Lund: Studentlitteratur.

Williams, M.J. (2008) '(In)Security Studies, Reflexive Modernization and the Risk Society', Cooperation and Conflict, 43(1), pp. 57-79. Available at: doi:10.1177/0010836707086737 (Accessed 19 December 2019).

\section{Official documents}

Government Offices of Sweden: Ministry of Defence (1992) Regeringens proposition 1991/92:102: Totalförsvarets utvecklingen till och med budgetåret 1996/97 samt anslag för budgetåret 1992/93 [online]. Available at: www.riksdagen. se/sv/dokument-lagar/dokument/proposition/totalforsvarets-utvecklingtill-och-med-budgearet_GF03102 (Accessed 3 February 2020).

Government Offices of Sweden: Ministry of Defence (1995) Departementsskrivelse 1995:28: Sverige i Europa och världen. Stockholm: Fritzes.

Government Offices of Sweden: Ministry of Defence (1995) Departementsskrivelse 1995:51: Totalförsvarets utveckling och förnyelse. Stockholm: Fritzes.

Government Offices of Sweden: Ministry of Defence (1995) Regeringens proposition 1995/96:12: Totalförsvar i förnyelse [online] Available at: www.riksdagen.se/sv/ dokument-lagar/dokument/proposition/totalforsvar-i-fornyelse_GJ0312 (Accessed 1 February 2020). 
Government Offices of Sweden: Ministry of Defence (1995) Statens offentliga utredningar 1995:19: Ett säkrare samhälle. Stockholm: Fritzes.

Government Offices of Sweden: Ministry of Defence (1996) Departementsskrivelse 1996:51: Omvärldsförändringar och svensk säkerhetspolitik. Stockholm: Fritzes.

Government Offices of Sweden: Ministry of Defence (1996) Regeringens proposition 1996/97:4: Totalförsvar i förnyelse - etapp 2 [online]. Available at: www.riksdagen. se/sv/dokument-lagar/dokument/proposition/totalforsvar-i-fornyelse---etapp2_GK034 (Accessed 1 February 2020).

Government Offices of Sweden: Ministry of Defence (1998) Departementsskrivelse 1998:9: Svensk säkerhetspolitik i ny omvärldsbelysning. Stockholm: Fritzes.

Government Offices of Sweden: Ministry of Defence (1999) Departementsskrivelse 1999:2: Förändrad omvärld - omdanat försvar. Stockholm: Fakta info direkt.

Government Offices of Sweden: Ministry of Defence (1999) Departementsskrivelse 1999:55: Europas säkerhet - Sveriges försvar. Stockholm: Fakta info direkt.

Government Offices of Sweden: Ministry of Defence (1999) Regeringens proposition 1999/2000:30: Det nya försvaret [online]. Available at: www.regeringen.se/ rattsliga-dokument/proposition/1999/11/prop.-1999200030/ (Accessed 3 February 2020).

Government Offices of Sweden: Ministry of Defence (2001) Departementsskrivelse 2001:14: Gränsöverskridande sårbarhet-gemensam säkerhet [online]. Available at: www.regeringen.se/rattsliga-dokument/departementsserien-och-promemorior/ 2001/03/ds-200114/ (Accessed 1 February 2020).

Government Offices of Sweden: Ministry of Defence (2001) Departementsskrivelse 2001:44: Ny struktur för ökad säkerhet - nätverksförsvar och krishantering [online]. Available at: www.regeringen.se/rattsliga-dokument/departementsserienoch-promemorior/2001/08/ds-200144/ (Accessed 1 February 2020).

Government Offices of Sweden: Ministry of Defence (2001) Regeringens proposition 2001/02:10: Fortsatt förnyelse av totalförsvaret [online] Available at: www. riksdagen.se/sv/dokument-lagar/dokument/proposition/fortsatt-fornyelse-avtotalforsvaret_GP0310 (Accessed 1 February 2020).

Government Offices of Sweden: Ministry of Defence (2001) Statens offentliga utredningar 2001:41: Säkerhet i en ny tid. Stockholm: Fritzes.

Government Offices of Sweden: Ministry of Defence (2003) Departementsskrivelse 2003:8: Säkrare grannskap - osäker värld [online]. Available at: www.regeringen. se/rattsliga-dokument/departementsserien-och-promemorior/2003/02/ds-20038/ (Accessed 1 February 2020).

Government Offices of Sweden: Ministry of Defence (2003) Departementsskrivelse 2003:34: Vårt militära försvar: vilja och vägval [online]. Available at: www. regeringen.se/rattsliga-dokument/departementsserien-och-promemorior/2003/ 06/ds-200334/ (Accessed 1 February 2020).

Government Offices of Sweden: Ministry of Defence (2004) Departementsskrivelse 2004:30: Försvar för en ny tid [online] Available at: www.regeringen.se/rattsligadokument/departementsserien-och-promemorior/2004/06/ds-200430/ (Accessed 1 February 2020).

Government Offices of Sweden: Ministry of Defence (2004) Regeringens proposition 2004/05:5: Vårt framtida försvar [online]. Available at: www.riksdagen.se/sv/ dokument-lagar/dokument/proposition/vart-framtida--forsvar_GS035 (Accessed 1 February 2020). 
Government Offices of Sweden: Ministry of Defence (2006) Departementsskrivelse 2006:1: En strategi för Sveriges säkerhet [online]. Available at: www.regeringen. se/rattsliga-dokument/departementsserien-och-promemorior/2006/01/ds-20061/ (Accessed 1 February 2020).

Government Offices of Sweden: Ministry of Defence (2007) Departementsskrivelse 2007:46: Säkerhet i samverkan: Försvarsberedningens omvärldsanalys [online]. Availableat:www.regeringen.se/rattsliga-dokument/departementsserienoch-promemorior/2007/12/ds-200746/ (Accessed 1 February 2020).

Government Offices of Sweden: Ministry of Defence (2008) Regeringens proposition 2007/08:92: Stärkt krisberedskap - för säkerhets skull [online]. Available at: www.regeringen.se/rattsliga-dokument/proposition/2008/03/prop.-20070892/ (Accessed 3 February 2020).

Government Offices of Sweden: Ministry of Defence (2009) Regeringens proposition 2008/09:140: Ett användbart försvar [online] Available at: www.riksdagen. se/sv/dokument-lagar/dokument/proposition/ett-anvandbart-forsvar_GW03140 (Accessed 1 February 2020).

Government Offices of Sweden: Ministry of Defence (2013) Departementsskrivelse 2013:33: Vägval i en globaliserad värld [online]. Available at: www.regeringen.se/ rattsliga-dokument/departementsserien-och-promemorior/2013/05/ds-201333/ (Accessed 1 February 2020).

Government Offices of Sweden: Ministry of Defence (2014) Departementsskrivelse 2014:20: Försvaretav Sverige: Starkareförsvar för en osäker tid[online]. Available at: www.regeringen.se/rattsliga-dokument/departementsserien-och-promemorior/ 2014/05/ds-201420/ (Accessed 1 February 2020).

Government Offices of Sweden: Ministry of Defence (2015) Regeringens proposition 2014/15:109: Försvarspolitisk inriktning - Sveriges försvar 2016-2020 [online] Available at: www.regeringen.se/rattsliga-dokument/proposition/2015/04/prop.201415109/ (Accessed 1 February 2020).

Government Offices of Sweden: Ministry of Defence (2017) Departementsskrivelse 2017:66: Motståndskraft: Inriktningen av totalförsvaret och utformningen av det civila försvaret 2021-2025 [online]. Available at: www.regeringen.se/rattsligadokument/departementsserien-och-promemorior/2017/12/ds-201766/ (Accessed 1 February 2020).

Government Offices of Sweden: Prime Minister's Office (2017) National Security Strategy. Available at: www.government.se/information-material/2017/10/ national-security-strategy/ (Accessed 3 February 2020). 